\title{
UTILIZATION OF EARTHWORMS IN ORGANIC WASTE MANAGEMENT
}

\author{
P. Alagesan* and R. Dheeba \\ Post Graduate and Research Department of Zoology, Yadava College, Tamil Nadu, India \\ *Corresponding author: E-Mail: maniragavi@rediffmail.com \\ Tel- + + 91452 2680362, Fax- ++ 914522682180
}

\begin{abstract}
Vermicomposting is an ecofriendly, socially sound and economically viable technology to manage the organic waste resources. It is popular particularly in India, because it is the cheapest solution to overcome the dangerous effects of modernized agriculture. The aim of the present study was to evaluate the efficiency and the nutritional status of vermicompost processed by two earthworm species, Eisenia fetida and Eudrilus eugeniae from leaf litter and sugarcane trash. Chemical analysis of the vermicompost obtained from leaf litter showed that the quantity of organic carbon was reduced from 38.65 to 28.89 and $28.0 \%$ by E. fetida and E. eugeniae respectively. The level of nitrogen $(1.30 \%)$, phosphorus $(0.38 \%)$, potassium $(0.57 \%)$ and calcium $(0.70 \%)$ was maximum in leaf litter vermicompost processed by E. eugeniae than E. fetida. Similarly, E. eugeniae processed leaf litter compost treated with plant, Abelmoschus esculentus showed maximum height $(61.4 \mathrm{~cm})$, number of leaves $\left(16\right.$ per plant), leaf area $\left(265 \mathrm{~cm}^{2}\right)$, fruit length $(15.8 \mathrm{~cm})$, fruit weight $(17.9 \mathrm{gm})$ and total chlorophyll content $(3.78 \mathrm{mg} / \mathrm{g}$. fresh $\mathrm{wt})$ than those treated with sugarcane trash.
\end{abstract}

Key words: Eisenia fetida, Eudrilus eugeniae, Abelmoschus esculentus

\section{INTRODUCTION}

One of the major problems associated with urbanization is the disposal of large amount of solid wastes generated from domestic, industries and agricultural residues. The accumulation of such wastes is increasing in an alarming way leading to the greater environmental degradation. Agriculture provides plenty of waste consisting of crop straw, husk, sugarcane trash, groundnut shells and generation of these wastes in India have been estimated to be 363 million tonnes annually (Chaudhary et al., 2004). Uncared dumping of leaf litter in public places and in the premises of educational institutions might lead to decomposition of solid wastes particularly during rainy season resulting in air, water and soil pollution. It also causes social, ecological, aesthetic and economic problems having a negative impact on human health and quality of life (Techobanoglous et al.1993). Hence, these wastes must be treated holistically, recognizing their natural resource origin as well as health impacts. All these problems encourage revival of old traditional techniques of compost production and organic farming which are nature's ways to renew life. During composting, the waste organic materials are broken down into different viable organic products that can be added to the soil without detrimental effects on crop growth. Compost improves soil structure, texture, and aeration and increases the soil's water-holding capacity. The organic matter produced in compost provides food for micro-organisms, which keeps the soil healthy and suppress diseases in plants (Hari et al., 2004). As this conventional method of composting takes a long time to produce compost, earthworms are inoculated with organic wastes which speed up the process of composting (Vermicomposting) and enhanced nutritional quality of the composts. Earthworms form a major component of the soil system and represent a key component in nutrient cycling of soils. In recent years researchers have become progressively interested in using earthworms for breaking down and stabilizing the wide variety of organic wastes (Atiyeh et al., 2000). The ability of some species of earthworms to consume and breakdown a wide range of organic residues especially crop residues is well known (Karmegam

Proceedings of the $15^{\text {th }}$ International Forestry and Environment Symposium, 26-27 November 2010.

Published by Department of Forestry and Environmental Science, University of Sri Jayewardenepura, Sri Lanka. 
and Daniel, 2009; Patnaik and Reddy, 2010). The microorganisms present in the gut of earthworm help in degradation of organic materials (Edwards and Bohlen, 1996).

The most frequently used earthworm species for vermicomposting are Eisenia fetida and Eudrilus eugeniae. The earthworm, E. eugeniae is commonly known as African worm or Night crawlers. It is a large composting worm, less tolerant to cold temperatures and best suited to tropical conditions. It is epigeic, lives on the surface of the soil or in the top 10 inches from the surface or on the topsoil under the litter layers. E. fetida popularly known as European worm is also epigeic, can tolerate wide temperature ranges. E. fetida is commonly found in compost heaps, forests, gardens, under stones and logs. The present study was aimed to evaluate the efficiency and nutritional status of the vermicompost and its effect on Abelmoschus esculentus, processed from the leaf litter and sugarcane trash by two earthworms, E. fetida and E. eugeniae.

\section{MATERIALS AND METHODS}

\subsection{COLLECTION OF COMPOST MATERIALS}

The leaf litter was collected from Yadava College campus and the sugarcane trash from the Alanganallur Sugar factory and were shredded to a length of 2-3 cm pieces, dried for a week and then subjected to pre decomposition. These wastes were mixed with equal amount of fresh cow dung in plastic troughs separately and allowed for predigestion by sprinkling water. After 30 days, the predigested substrates were subjected to vermicomposting.

\subsection{COLLECTION AND MAINTENANCE OF EARTHWORMS}

The earthworm species, E. eugeniae and E. fetida chosen for the present study were collected from SACS Vermiery, Near Chatrapatty, Madurai District. The earthworms were acclimatized to the laboratory conditions for a period of 15 days before the commencement of the experiment.

\subsection{VERMIBED PREPARATION}

From the predigested materials of leaf litter and sugarcane trash, $5 \mathrm{~kg}$ from each lot was taken separately in three rectangular culture troughs of equal size $(47 \times 32 \times 16 \mathrm{~cm})$. Among the three troughs, first one was without the earthworms, second and third with E. fetida, E. eugeniae respectively. Fifty earthworm species of E. fetida and E. eugeniae were introduced separately in the second and third troughs of leaf litter and sugarcane trash respectively. Water was sprinkled with regular intervals in all the troughs to maintain the temperature at $25^{\circ} \mathrm{C}$ and the troughs were covered with wet muslin cloth. The vermicomposting process was extended for a period of 45 days in three replicates.

\subsection{BIOCHEMICAL ANALYSIS}

Before introducing the earthworms into the troughs i.e. at the initial ( 0 day) and after $45^{\text {th }}$ day, the samples of compost and vermicompost were analyzed for the following biochemical components. The organic carbon was estimated following Walkey and Black method as described in Jackson (1973). The nitrogen content was determined by the modified Micro-Kjeldhal method (Umbreit $e t$ al., 1974). The phosphorous was estimated according to the standard method of APHA (1998). The amount of potassium and calcium present in the samples were estimated with the help of Flame Photometry (Model CL - 22D). 


\subsection{POT EXPERIMENT}

To examine the fertility of the leaf litter and sugarcane trash composts processed by earthworms, the vegetable plant, Abelmoschus esculentus (L) Moench, was selected. $3 \mathrm{~kg}$ of garden soil, composts and vermicomposts of the leaf litter and sugarcane trash were taken in separate individual pots and in each pot 10 seeds of A. esculentus were sown and maintained for a period of 50 days. Five replicates were maintained for each experiment. The data related to growth parameters of the plant i.e., height of the plant, number and area of leaves and length and weight of the fruits were observed and recorded at regular intervals. The total chlorophyll content of the matured leaves of control and experimental plants were estimated by following the method of Arnon (1949).

\section{RESULTS AND DISCUSSION}

The chemical composition of the vermicomposts produced from the leaf litter and sugarcane trash by the activity of the earthworms, E. fetida and E. eugeniae are presented in Tables $1 \& 2$. Statistical analysis revealed that the quantity of nitrogen, phosphorus, potassium and calcium is positively correlated with the duration of vermicomposting $(\mathrm{P}<0.05)$. But the organic carbon and $\mathrm{C} / \mathrm{N}$ ratio were negatively correlated with the advancement of vermicomposting.

Table 1: Nutrient composition of vermicompost of leaf litter processed by E. fetida and $E$. eugeniae. Each value represents the mean of $(\mathrm{X} \pm$ S.D) 5 estimates

\begin{tabular}{|l|l|l|l|l|}
\hline \multirow{2}{*}{ Parameters } & \multirow{2}{*}{$\begin{array}{l}0 \text { day } \\
\text { (Initial) }\end{array}$} & \multirow{2}{*}{ Compost } & \multicolumn{3}{|c|}{$45^{\text {th }}$ Day } \\
\cline { 3 - 5 } & & & Eermicompost processed by \\
\hline Organic Carbon (\%) & $38.65 \pm 0.65$ & $30.48 \pm 0.52$ & $28.89 \pm 0.81$ & $28.00 \pm 0.78$ \\
\hline Total Nitrogen (\%) & $0.85 \pm 0.03$ & $1.01 \pm 0.01$ & $1.18 \pm 0.02$ & $1.30 \pm 0.03$ \\
\hline Phosphorus (\%) & $0.16 \pm 0.01$ & $0.25 \pm 0.01$ & $0.33 \pm 0.02$ & $0.38 \pm 0.01$ \\
\hline Potassium (\%) & $0.28 \pm 0.02$ & $0.43 \pm 0.02$ & $0.52 \pm 0.03$ & $0.57 \pm 0.03$ \\
\hline Calcium $(\%)$ & $0.22 \pm 0.03$ & $0.51 \pm 0.03$ & $0.62 \pm 0.05$ & $0.70 \pm 0.04$ \\
\hline
\end{tabular}

\subsection{ORGANIC CARBON}

The percentage of organic in the compost prepared from the leaf litter without earthworms has reduced from 38.65 to $30.48 \%$ at the end of $45^{\text {th }}$ day of the experiment. Maximum reduction in the organic carbon content was observed (28\%) in the leaf litter vermicompost processed by earthworms, E. eugeniae than E.fetida (34.28\%). The percentage of carbon has reduced from the initial day $(44.54 \%)$ to the final day of sugarcane trash compost $(39.13 \%)$. But it was tremendously reduced to 35.91 and $34.28 \%$ at the end of $45^{\text {th }}$ day by the action of E. fetida and E. eugeniae, respectively. Similarly, Gajalakshmi et al., (2005) reported a significant carbon decrease in the leaf litter processed by E. eugeniae. Garg et al., (2005) have reported that reduction in total organic carbon was highest in agro-residues treated with E. fetida. Edwards and Lofty (1977) indicated that it is mainly due to combusting of carbon during respiration. Discussing the reduction of organic carbon, Mariappan et al., (2003) pointed out that decomposition of organic matter is brought about 
by living organisms that use more carbon than nitrogen as a source of energy and thus the amount of carbon is reduced to a more suitable level while nitrogen is recycled.

Table 2: Nutrient composition of vermicompost of sugarcane trash processed by E. fetida and $E$. eugeniae. (Each value represents the mean of $(\mathrm{X} \pm$ S.D) 5 estimates)

\begin{tabular}{|l|l|l|l|l|}
\hline \multirow{2}{*}{ Parameters } & \multirow{2}{*}{$\begin{array}{l}\text { 0 day } \\
\text { (Initial) }\end{array}$} & \multirow{2}{*}{ Compost } & \multicolumn{3}{|c|}{$45^{\text {th }}$ Day } \\
\cline { 4 - 5 } & & & Eermicompost processed by \\
\hline Organic Carbon (\%) & $44.54 \pm 1.01$ & $39.13 \pm 2.03$ & $35.91 \pm 0.98$ & $34.28 \pm 2.99$ \\
\hline Total Nitrogen (\%) & $0.74 \pm 0.04$ & $0.91 \pm 0.02$ & $1.12 \pm 0.02$ & $1.18 \pm 0.04$ \\
\hline Phosphorus (\%) & $0.12 . \pm 0.02$ & $0.24 \pm 0.01$ & $0.26 \pm 0.02$ & $0.28 \pm 0.01$ \\
\hline Potassium (\%) & $0.16 \pm 0.03$ & $0.29 . \pm 0.02$ & $0.37 \pm 0.03$ & $0.41 \pm 0.01$ \\
\hline Calcium $(\%)$ & $0.19 \pm 0.01$ & $0.31 \pm 0.01$ & $0.53 \pm 0.03$ & $0.64 \pm 0.03$ \\
\hline
\end{tabular}

\subsection{TOTAL NITROGEN}

The nitrogen content was comparatively higher $(0.85 \%)$ in the leaf litter than the sugarcane trash $(0.74 \%)$ at the initial stage and at the end of $45^{\text {th }}$ day it had increased to $1.01 \%$ and $0.91 \%$ without earthworms. But the vermicompost prepared from the leaf litter showed a very high percentage of nitrogen $(1.30 \%)$ by E. eugeniae than E. fetida $(1.18 \%)$. The level of nitrogen was found to be $1.18 \%$ and $1.12 \%$ at the $45^{\text {th }}$ day of vermicompost prepared from sugarcane trash processed by $E$. eugeniae and E. fetida respectively. Similarly, Parthasarathi and Renganathan (1999) reported that E. eugeniae increased the content of nitrogen 3.07 times over the ordinary compost. Sharma and Agarwal (2004) pointed out that earthworm casts contain five times more nitrogen than ordinary compost. The high degree of decomposition and mineralization increases high nitrogen content of soil which may fix atmospheric nitrogen in significant quantities and act as the source of nitrogen for plant growth (Hari et al., 2004).

\subsection{C/N RATIO}

Maximum C/N ratio (60.19) was in sugarcane trash and it was found to be less in leaf litter (45.47) at the initial stage (Fig.1).

The $\mathrm{C} / \mathrm{N}$ ratio of leaf litter degraded by both E. fetida and E. eugeniae had been reduced significantly to lower level (24.48 and 22.40) than the compost (30.18). The $\mathrm{C} / \mathrm{N}$ ratio of the sugarcane trash vermicompost at the $45^{\text {th }}$ day was found to be 32.06 and 29.05 processed by $E$. fetida and E. eugeniae respectively. The $\mathrm{C} / \mathrm{N}$ ratio is an important factor affecting fertility of soil which is considerably altered by earthworms. Bansal and Kapoor (2000) reported that lowering of $\mathrm{C} / \mathrm{N}$ ratio is due to loss of carbon in bacterial metabolism. Scanning of literatureshows that the optimum values for $\mathrm{C} / \mathrm{N}$ ratio ranges from 20 to 31 (Sinha et al., 2003; Zhu, 2007). Jeyabal and Kuppuswamy (2001) observed the C/N ratio of vermicompost reduced to 12-17:1 from 21-69:1 by E. eugeniae. The earthworm, E. fetida reduced the $\mathrm{C} / \mathrm{N}$ ratio considerably in the compost prepared from agro wastes (Tripathi and Bhardwaj, 2003). 


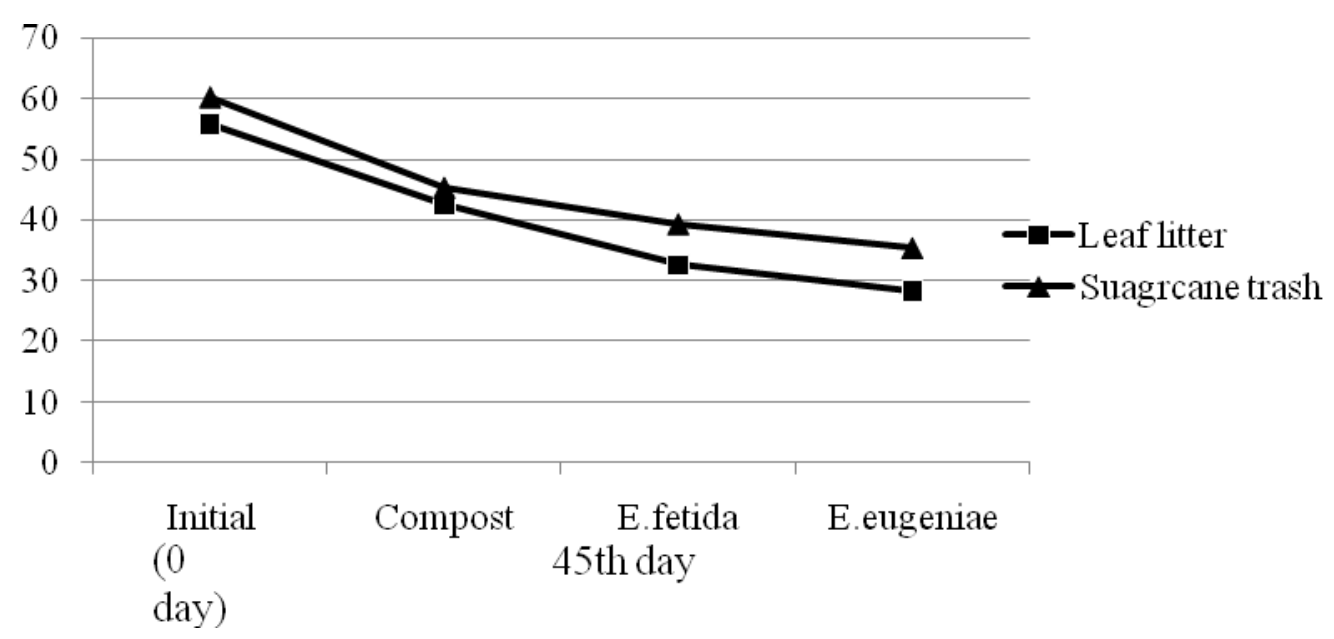

Figure 1: $\mathrm{C} / \mathrm{N}$ ratio of composted leaf litter and sugarcane trash

\subsection{PHOSPHORUS}

At the commencement of composting, the quantity of phosphorus was 0.16 and $0.12 \%$ in leaf litter and sugarcane trash respectively. After 45 days, the compost without earthworms contained less amount of phosphorus $(0.24$ and $0.25 \%)$ than the vermicomposts obtained from sugarcane trash $(0.26$ and $0.28 \%)$ and leaf litter $(0.33$ and $0.38 \%)$ by the activities of E. fetida and E. eugeniae respectively. It is concluded that the phosphorus content was higher (1.08-1.52 times) in worm worked compost than the conventional composts. Sharma and Agarwal (2004) reported that earthworm casts contain seven times phosphorus more than ordinary soil. Garg et al., (2005) noticed that the content of phosphorus had increased 1.4 to 6.5-fold in different substrates processed by E. fetida in comparison to control. Phosphorus increase is due to the microbial and phosphatase activity and increased solubility of phosphate in the vermicompost (Tiwari et al., 1989). Scubler et al., (1998) reported that phosphorus is bound in organic matter in a form that is not available to plants; but mixing action of earthworms change it into a form that can be absorbed by the plant.

\subsection{POTASSIUM}

The potassium content of the compost obtained from leaf litter was higher $(0.28 \%)$ than the sugarcane trash $(0.16 \%)$ at the beginning of the composting. The leaf litter composted by $E$. eugeniae contained more potassium $(0.57 \%)$ than sugarcane trash $(0.41 \%)$. The earthworm, $E$. fetida was also very effective in increasing the content of potassium in the leaf litter compost $(0.52 \%)$ and sugarcane trash $(0.37 \%)$. Sharma and Agarwal (2004) reported that earthworm casts contain eleven times more potassium than ordinary compost. Basker, et al., (1993) pointed out that the potassium enhancement is due to shifting of non exchangeable to exchangeable form. Similar increasing trend in the level of potassium was noticed by Umamaheshwari et al., (2004) in the vermicompost obtained through the action of E. eugeniae.

\subsection{CALCIUM}

The level of calcium at the initial stage was reported as 0.19 and $0.22 \%$ in sugarcane trash and leaf litter respectively. E. eugeniae increased the calcium level to 0.64 and $70 \%$ in sugarcane trash and leaf litter after 45 days of composting. A similar trend in calcium increase was noticed in vermicomposts of both sugarcane trash $(0.53 \%)$ and leaf litter $(0.62 \%)$. This elevation may be due to microbes in the gut of earthworms and their metabolic process (Sudhakar et al., 2002). 


\subsection{POT EXPERIMENT}

Data related to the effect of different compost processed by E. fetida and E. eugeniae on the growth parameters of the vegetable plant, Abelmoschus esculentus is presented in Table 3. The results revealed that the plants grown on leaf litter vermicompost processed by E. eugeniae attained maximum height $(61.4 \mathrm{~cm})$ compared to sugarcane trash vermicompost (56.75), composts without earthworms (leaf litter: $33 \mathrm{~cm}$; sugarcane trash: $25.8 \mathrm{~cm})$ and garden soil $(20.3 \mathrm{~cm})$.

Table 3: Effect of leaf litter and sugarcane trash composted with earthworms on the growth parameters of Abelmoschus esculentus (after 50 days of life). Each value represents as mean (X \pm S.D) of 5 observations

\begin{tabular}{|c|c|c|c|c|c|c|c|}
\hline \multirow{3}{*}{$\begin{array}{l}\text { Parameter } \\
\mathrm{s}\end{array}$} & \multirow{3}{*}{$\begin{array}{l}\text { Garden } \\
\text { soil }\end{array}$} & \multicolumn{3}{|l|}{ Leaf litter } & \multicolumn{3}{|c|}{ Sugarcane trash } \\
\hline & & \multirow[t]{2}{*}{$\bar{C}$} & \multicolumn{2}{|l|}{$\mathrm{Vc}$} & \multirow[t]{2}{*}{$\mathrm{C}$} & \multicolumn{2}{|l|}{$\mathrm{Vc}$} \\
\hline & & & $E f$ & $E e$ & & $E f$ & $E e$ \\
\hline $\begin{array}{l}\text { Height of } \\
\text { plant }(\mathrm{cm})\end{array}$ & $\begin{array}{ll}20.3 & \pm \\
2.05 & \end{array}$ & $\begin{array}{ll}33.0 & \pm \\
1.84 & \end{array}$ & $\begin{array}{ll}54.8 & \pm \\
3.21 & \end{array}$ & $\begin{array}{ll}61.4 & \pm \\
3.25 & \end{array}$ & $\begin{array}{ll}25.8 & \pm \\
2.41 & \end{array}$ & $\begin{array}{l}42.23 \quad \pm \\
4.46\end{array}$ & $\begin{array}{l}56.75 \quad \pm \\
3.45\end{array}$ \\
\hline $\begin{array}{ll}\text { No. of } \\
\text { leaves }\end{array}$ & $\begin{array}{l}7.1 \pm \\
0.66\end{array}$ & $\begin{array}{ll}9.85 & \pm \\
0.81 & \end{array}$ & $\begin{array}{ll}13.6 & \pm \\
1.01 & \end{array}$ & $\begin{array}{ll}16.3 & \pm \\
1.15 & \end{array}$ & $\begin{array}{l}8.62 \pm \\
0.78\end{array}$ & $\begin{array}{ll}10.3 & \pm \\
0.81 & \end{array}$ & $\begin{array}{ll}14.3 & \pm \\
0.49 & \end{array}$ \\
\hline $\begin{array}{l}\text { Leaf area } \\
\left(\mathrm{cm}^{2}\right)\end{array}$ & $\begin{array}{ll}77.89 \quad \pm \\
5.1\end{array}$ & $\begin{array}{l}118.24 \pm \\
10.66\end{array}$ & $\begin{array}{l}194.31 \pm \\
8.6\end{array}$ & $\begin{array}{l}265.23 \pm \\
12.36\end{array}$ & $\begin{array}{l}99.87 \pm \\
10.2\end{array}$ & $\begin{array}{l}164.23 \pm \\
12.75\end{array}$ & $\begin{array}{l}221.25 \pm \\
15.32\end{array}$ \\
\hline $\begin{array}{l}\text { Fruit } \\
\text { length } \\
(\mathrm{cm})\end{array}$ & $\begin{array}{l}7.6 \\
0.81\end{array}$ & $\begin{array}{l}9.56 \\
0.95\end{array}$ & $\begin{array}{l}14.2 \\
1.02\end{array}$ & $\begin{array}{l}15.8 \\
1.51\end{array}$ & $\begin{array}{l}8.5 \\
0.71\end{array}$ & $\begin{array}{l}12.7 \\
1.25\end{array}$ & $\begin{array}{l}14.9 \\
1.29\end{array}$ \\
\hline $\begin{array}{l}\text { Fruit } \\
\text { weight } \\
(\mathrm{gm})\end{array}$ & $\begin{array}{l}10.6 \\
1.77\end{array}$ & $\begin{array}{l}13.7 \\
1.24\end{array}$ & $\begin{array}{l}15.1 \\
1.14\end{array}$ & $\begin{array}{l}17.9 \\
1.81\end{array}$ & $\begin{array}{l}11.5 \\
0.33\end{array}$ & $\begin{array}{l}14.1 \\
1.28\end{array}$ & $\begin{array}{l}16.7 \\
1.14\end{array}$ \\
\hline $\begin{array}{l}\text { Chlorophyl } \\
1 \quad \text { (mg/g } \\
\text { fresh wt.) }\end{array}$ & $\begin{array}{l}1.90 \\
0.73\end{array}$ & $\begin{array}{ll}2.51 & \pm \\
0.90 & \end{array}$ & $\begin{array}{ll}3.38 & \pm \\
0.89 & \end{array}$ & $\begin{array}{ll}3.78 & \pm \\
0.15 & \end{array}$ & $\begin{array}{ll}2.01 & \pm \\
0.88 & \end{array}$ & $\begin{array}{ll}2.86 & \pm \\
0.20 & \end{array}$ & $\begin{array}{l}3.41 \\
0.22\end{array}$ \\
\hline
\end{tabular}

C- Compost; Vc- Vermicompost; Ef- E.fetida; Ee- E. eugeniae

Similarly, other parameters including number (16/plant) and area of leaves $\left(265.23 \mathrm{~cm}^{2}\right)$, length $(15.8 \mathrm{~cm})$ and weight $(17.9 \mathrm{gm})$ of the fruits, and chlorophyll content $(3.78 \mathrm{mg} / \mathrm{g}$ fresh wt.) were greater in leaf litter vermicompost than the sugarcane trash processed by E. eugeniae. The results of the pot experiments have shown that the vermicompost of the tested organic waste highly altered the growth parameters of the plant Abelmoschus esculentus. Viveka et al., (2005) observed the influence of vermicomposts in the growth and yield of bhendi plants. Ismail (2005) observed significantly higher yield of lady's finger, chillies, water melon and paddy by vermicompost application than farm yard manure. The positive effects of vermicompost on the tested plants may be because nutrients present in the worm cast are readily soluble in water for the uptake of plants (Bhawalkar and Bhawalkar, 1993). In the present investigation, leaf litter vermicompost showed higher values for the growth parameters of Abelmoschus esculentus than the sugarcane trash. This is due to the fact that nutrient status of vermicompost depends on the quality of waste materials used for processing by the earthworms as pointed out by Bohlen et al., (1999). The leaf tissues of A. esculentus grown on leaf litter vermicompost showed high quantity of chlorophyll pigments than those reared on sugarcane trash composted with earthworms. Nithya et al., (2006) concluded that plants grown in soil amended with vermicompost show higher primary productivity by way of 
increased synthesis and elevated photosynthetic activity which in turn increase the yield of the plant.

From the present study it is revealed that of the two species of earthworms, E. eugeniae is highly efficient in composting the wastes into useful organic manure than E. fetida. This is because of its huge size, feeding rate, size and moisture content of the casts, microbial population and enzymatic action in the gut and casts as reported by Vinotha (1999).

\section{CONCLUSIONS}

The chemical analysis of the vermicomposts derived from leaf litter showed that the quantity of organic carbon was reduced from 38.65 to 28.89 and $28 \%$ by E. fetida and E. eugeniae respectively. The level of nitrogen, phosphorus, potassium and calcium was higher in vermicompost processed by E. eugeniae than E. fetida in both leaf litter and sugarcane trash. An ideal $\mathrm{C} / \mathrm{N}$ ratio (22.40) was observed in leaf litter vermicompost processed by $E$. eugeniae. Similarly, E. eugeniae worked leaf litter vermicompost positively and significantly altered the height, number and area of leaves, fruit length and weight of Abelmoschus esculentus.

\section{ACKNOWLEDGEMENTS}

The authors thank the Principal and Mangement Committee of Yadava College for providing the necessary facilities.

\section{REFERENCES}

APHA. 1998. Standard Methods for the Examinations of Water and Wastewater, American Public Health Association $20^{\text {th }}$ ed. Washington, D.C., U.S.A.

Atiyeh, R., M., Subler, N., Edwards, C.A., Bachman, G., Metzger J.D., and Shuster, W. 2000. Effects of vermicomposts and composts on plant growth in horticultural container media and soil. J.Pedobiologia, 44, 579- 590.

Arnon, D.I., 1949 Copper enzyme in isolated chloroplasts. Plant Physiol, 24, 1-5.

Bansal, S., and Kapoor, K.K., 2000. Vermicomposting of crop residues and cattle dung with Eisenia fetida. J. Bioresour. Technol, 73, .95-98.

Basker, A., Macgregor, A.N., and Kirkman, J.H., 1993. Exchangeable potassium and other cations in non ingested soil and casts of two species of pastures earthworms. Soil Biol.Biochem. 25 (2), 1673-1677.

Bhawalkar, U.S., and Bhawalkar, U.V., 1993. Organics in Soil Health and Crop Production. (ed., P.K. Thampan). Peekay Tree crops Development Foundation, Cochin, 69-85.

Bohlen, P.J., Parmelee, R.W., Allen, M.F., Ketterings, G.M., 1999. Differential effects of earthworms on nitrogen cycling from various nitrogen 15 labeled substrates. Amer..J. Soil Sci. Soc. 63, 882-890.

Chaudhary, D.R., Bhandari, S.C., and Shukla, L.M., 2004. Role of vermicompost in sustainable Agriculture - A Review. J. Agri. Rev. 25(1), 29-39.

Edwards, C.A., and Bohlen, P.J., (1996) Biology and ecology of earthworms. Third ed. Chapman and Hall, London, 26-31.

Edwards, C. A., and Lofty J. R., 1977) Biology of earthworms, Chapman and Hall, London, 54-69. 
Gajalakshmi, S., Ramasamy, E.V., and Abbasi, S.A., 2005. Composting - Vermicomposting of Leaf litter ensuing from the trees of mango (Mangifera indica). Bioresour. Technol. 96, 1057-1061.

Garg, P., Gupta, A., and Satya, S., 2005. Vermicomposting of different types of waste using Eisenia foetida: A comparative study. J.Environ. Biol. 26, (1), 7-12.

Hari, T.K., Thankamani, K., and Sushama, P.K., 2004.Value addition of compost enrichment studies', Agro.s Newsletter, 3 (V), 18-20.

Ismail, S.A., 2005 The Earthworm Book, Other India Press, Goa, India.45.

Jackson, M.L., 1973. Soil Chemical analysis, Prentice Hall of India, New Delhi, India, 87-89.

Jeyabal A., and Kuppuswamy, G., 2001. Recycling of organic wastes for the production of vermicompost and its response in rice-legume cropping system and soil fertility. Europ. J. Agron. 15, (3), 153-170.

Karmegam, N., and Daniel, T., 2009. Investigating efficiency of Lampito mauritii (Kinberg) and Perionyx ceylanensis (Michaelsen) for vermicomposting of different types of organic substrates. The Environmentalist. 29(3), 287-300.

Mariappan, V., Rajan, M., and Ramasubramanian, V., 2003. Influence of organic and inorganic amendments in tannery affected soil on growth and biochemical characteristics of Hardiwickia binata Roxb. J. Curr. Sci. 91, 19-24.

Nithya, S., Sathish Kumar, N., Vijayakumar, K., Senthil Murugan. S., and Ramaswamy, M., 2006. A study on the biomass increase of earthworm, Eudrilus eugeniae (kinberg) and yield of vermicompost during vermicomposting of leaf litter. J. Ecol.Res. Biocon.7 (1\&2), 30-36.

Parthasarathi, K., and Ranganathan, L.S., 1999. Longevity of microbial enzyme activity and their influence on NPK content in pressmud vermicasts. Europ.J.Soil Biol.35 (3), 107-113.

Patnaik, S., and Reddy, M.V., 2010. Nutrient status of vermicompost of urban green waste processed by three earthworm species, Eisenia fetida, Eudrilus eugeniae and Perionyx excavates. Appl.Environ.Soil Sci. 1-13.

Scubler, S., Edwards, C.A., and Metzer, J., 1998. Comparing vermicomposts and Composts. Biocycle. 7, 6366.

Sharma, A., and Agarwal, A.K., 2004. Organic farming - Todays evolution, Tomorrows prosperity. $J$. Agrobios, 3, 16-18

Sinha, M.P., Srivastava, R., Kumar, M., and Singh, M.P.N., 2003. Laboratory observations on C/N ratio of soil by earthworm inoculation. Asian J. Microbiol. Biotecnol. Environ. Sci. 5(2), 225-117.

Sudhakar, G., Christopher, A., Ramasamy, A., Subbiah, P., and Velayutham. A., 2002. Effect of vermicompost application on the soil properties, nutrient availability, uptake and yield of rice. Agri.Rev. 23 (2), 127-132.

Techobanoglous, G., Teheiscn, H., and Avigil., S., 1993. Integrated Solid Waste Management. Mc Graw Hill Inc. New York. 241-250. 
Tiwari, S.C., Tiwari, B.K., and Mishra, R.R., 1989. Microbial populations, enzyme activities and nitrogen phosphorus - potassium enrichment in earthworm casts and in surrounding soil of a pineapple plantation. Biol.fert.Soil.8,178-182.

Tripathi, G., and Bhardwaj, P.,2003. Comparative studies on biomass production, life cycles and composting efficiency of Eisenia fetida (Savigny) and Lampito mauritii (Kinberg). Water Sci. Technol.48 (11-12), 125-132.

Umamaheswari, S., Balamurugan, V., and Vijaylakshmi, G.S., 2004. Degradation of leaf litter wastes by Earthworms. J. Ecobiol.16 (2), 153-155.

Umbreit, W.W., Burris, R.N., and Stauffer, J.F., 1974. Method for Nitrogen estimation. In: Manometric and Biochemical techniques. Burgess Publishing Company, Minneasota.358.

Vinotha, S.P.1999. Aging effect on microbial populations, NPK enrichments, enzyme activities in vermicasts and gut transit time of clay loam soil and pressmud in Perionyx excavatus (Perrier) and Eudrilus eugeniae (Kingberg) (Annelida: Oligochaeta). Ph.D thesis, Annamalai University, India.

Viveka, S., Vijayalakshmi, G.S., and Palaniappan, R., 2005. Effect of vermicomposted weeds on the growth and yield of Bhendi plant. Environ. Ecol. 23(1), 29-32.

Zhu, N., 2007. Effect of low initial C/N ratio on aerobic composting of swine manure with rice straw. Bioresour.Technol. 98(1), 9-13. 